\title{
MORTGAGE DEFAULT AND REPOSSESSION: PROCEDURE AND POLICY IN THE POST- NORGAN ERA
}

\section{Lara McMurtry, Lecturer in Law, Keele University}

It is a remarkable feature of contemporary mortgage law that the principal statutory protection for borrowers in short term financial difficulties is still to be found within the narrow confines of section 36 of the Administration of Justice Act 1970 (as amended). This provision bestows upon the court the discretion to temper the otherwise unfettered entitlement of a mortgage lender to possession of the mortgaged property. It serves as a counterweight to the common law right of a mortgagee to, "go into possession before the ink is dry on the mortgage unless there is something in the contract, express or by implication, whereby he has contracted himself out of that right". ${ }^{1}$ In possession cases, section 36 permits the court to adjourn proceedings, stay or suspend the execution of the judgment or delay the date for delivery of possession. This jurisdiction is, however, hedged with restrictions. By virtue of section 36(2), the discretion can be exercised only when 'the mortgagor is likely to be able within a reasonable period to pay any sums due under the mortgage or to remedy a default consisting of a breach of any other obligation arising under or by virtue of the mortgage'. Unfortunately, Parliament has failed to elaborate on the meaning to be given to its chosen phraseology and omitted to offer any guidelines as to how the court is to undertake this socially and economically sensitive task. To compound the difficulties facing the court, the drafting of section 36 is lamentable and has generated a variety of practical and interpretational difficulties. ${ }^{2}$ It is, therefore, against a backdrop of legislative imprecision and judicial temerity that the key decision of the Court of Appeal in Cheltenham \& Gloucester Plc v Norgan ${ }^{3}$ falls to be evaluated.

The Norgan case establishes the general rule that the remaining lifetime of the mortgage will offer the best guide from which to calculate 'a reasonable period' within which to repay sums due. This marks a radically different approach than that adopted previously and maximises the relief offered to the borrower. Few could sensibly object to this element of latitude as the Norgan approach applies only to cases where the security is not in jeopardy and the mortgagor can demonstrate an ability to discharge arrears by periodic payments. By way of reinforcing the notion that the economic interests of the lender are not to be relegated, the borrower must present a viable financial plan which demonstrates that the arrears (and future payments as they fall

1 Per Harman J in Four-Maids Ltd v Dudley Marshall (Properties) Ltd [1957] Ch. 317 at 320.

2 See, e.g. Ropaigealach v Barclays Bank Plc [2000] QB 263 (no discretion exists when the borrower is already out of possession); Western Bank v Schindler [1976] 2 All ER 393 (the discretion exists even when there is no borrower default) and Halifax Building Society v Clark [1973] Ch. 307 (meaning of 'any sums due' sufficiently wide to include the entire mortgage debt).

3 [1996] 1 All ER 449. 
due) can be managed by increased monthly payments over the remainder of the mortgage term. It was, moreover, anticipated that, once given the benefit of any judicial doubt, the borrower would be offered no further chance to clear the arrears. A breach of the terms of any suspension was not to be condoned and would result in the enforcement of the possession order. While representing the high water mark of borrower protection, the Norgan approach is based upon a commonsensical and commercially intuitive interpretation of section 36. In this way, the Court of Appeal attempted to promote social policy, preserve a family home for the borrower and ensure that the lender still receives the fruits of its bargain. ${ }^{4}$ The decision indubitably marks an attractive coalescence of otherwise competing interests.

The post-Norgan era is one characterised by historically low levels of repossession. A combination of reduced interest rates, a strong economy and labour market and a proliferation of competitive mortgage products have contributed to a prolonged period of significant growth in mortgage borrowing and consumer confidence. In the wake of this economic stability, the courts have been less troubled by the exercise of the section 36 discretion. The radical approach heralded by Norgan has, therefore, been marginalised during this period of economic prosperity. Unfortunately, this is set to change. Recent statistics reveal that the current level of repossessions is higher than at any point during the last six years ${ }^{5}$ and this is a trend that is likely to increase. Hence, a re-evaluation of the judicial treatment of mortgagors in temporary financial difficulties is particularly apposite in the current climate.

The impetus for such a review is irresistible. The effect of Norgan must be measured by evidence of consistency and fairness to both lenders and borrowers over a sustained period of time. Following the lapse of more than a decade, an analysis of intervening case law developments (such as they are) provides a necessary insight. Furthermore, the avowed refusal of the courts in Northern Ireland to embrace the Norgan ethos has fashioned some opportunity for comparative study. Underpinned by an alternative policy agenda, the Northern Ireland approach has become distinctive and entrenched. ${ }^{6}$ Nevertheless, and in light of adopted industry practice, this stance is clearly out of line with consumer expectation across the remainder of the United Kingdom. In addition, the policies and procedures of mortgage lenders have been the subject of major regulatory reform by the Financial Services Authority. ${ }^{7}$ The FSA Handbook, 'Mortgages: Conduct of Business Sourcebook' $(\mathrm{MCOB})^{8}$ imposes new procedural requirements on institutional

4 As Lord Denning MR famously remarked in Davis v Johnson [1979] AC 264 at 274 , "Social justice requires that personal rights should, in a proper case, be given priority over rights of property".

5 The latest CML statistics record 17,000 properties taken into possession in 2006, which marks a $65 \%$ increase on 2005 figures; see further http://cml.org.uk/cml/statistics.

6 See, e.g. National \& Provincial Building Society v Lynd [1996] NI 47.

7 This is pursuant to the Financial Services and Markets Act 2000. The mortgage specific provisions have been in full force since October 31, 2001.

8 See http://fsahandbook.info/FSA/hmtl/handbook/MCOB. From April 2007, the sourcebook is to become known as the 'Mortgages and Home Finance: Conduct of Business Sourcebook' (MCOB). 
lenders entering 'regulated mortgage contracts' on or after October 31, 2004. ${ }^{9}$ Most pertinently, the Sourcebook contains specific rules and guidance on dealing with cases of arrears and repossession. ${ }^{10}$ These flagship industry standards introduce a new dynamic into the interrelationship between the regulatory and the substantive statutory safeguards for the borrower. In a like vein, the enactment of the Consumer Credit Act 2006 provides an opportune moment for reflection. It is, however, to be appreciated that the 2006 Act maintains a distinctive regime for secured borrowing within its purview. ${ }^{11}$ In a context where proposals for the reform of the substantive law of mortgages remain shelved, ${ }^{12}$ the lack of a unified set of rules concerning the relief of the borrower is, arguably, intolerable and, most certainly, unjustifiable.

\section{Background}

The history leading up to the enactment of section 36 is well documented elsewhere ${ }^{13}$ and needs no in depth examination here. Nevertheless, in order to understand the present jurisdiction it is necessary to have some understanding of past judicial and Parliamentary machinations. A convenient starting point is the Practice Direction of 1936 which explicitly afforded the Chancery discretion to adjourn a summons. The discretion applied where possession was sought because the borrower was in arrears with instalments. It extended to cases where the High Court Master was of the opinion that the mortgagor ought to be given an opportunity to pay off the arrears. The creation of this discretion was reflective of societal change and arose from the perception that buying with the aid of a building society advance could expose homeowners to the risk of temporary financial difficulties. ${ }^{14}$ Unfortunately, this tenderness towards the borrower failed to give due weight to the commercial dynamic underlying the modern day mortgagee's need for possession as a pre-requisite of sale. The immediacy of the mortgagee's inherent right to take possession was subsequently to be rekindled by the High Court in Birmingham Citizens Permanent Building Society $v$ Caunt.$^{15}$ There Russell J reasserted the mortgagee's common law position and signalled the end of the liberal discretionary approach previously adopted in the Chancery court.

The decision in Caunt dismantled established practices and reduced the capacity for equitable intervention to a bare minimum. Indeed, relief was then available only to ensure that a mortgagor was not to be turned out of

9 A contract is a 'regulated mortgage contract' where the obligation of the borrower to repay is secured by a first legal mortgage and at least $40 \%$ of the land is used, or intended to be used, as or in connection with a dwelling: Financial Services and Markets Act 2000 (Regulated Activities) Order, Art. 61(3).

10 MCOB 12, 13.

11 See, e.g. the availability of time orders time orders under s.129.

12 See Transfer of Land - Land Mortgages, Law Com No.204 (1991); Land Mortgages, Law Com Working Paper No.99 (1986).

13 See M. Haley, "Mortgage Default: Possession, Relief and Judicial Discretion" (1997) 17 LS 483.

14 The development of a liberal judicial practice was, as Nourse J. commented in Mobil Oil Co Ltd v Rawlinson (1982) 43 P. \& C. R. 221 at 224, "no doubt assisted by the benevolent attitude which the Legislature had by then assumed towards tenants faced with eviction by their landlords".

15 [1962] Ch. 883. 
possession immediately without having the opportunity to repay the entire debt. The case for statutory reform was overwhelming. Consequently, the Payne Committee was established to consider, "whether the courts should have power otherwise to postpone the operation of an order for possession of the mortgaged property". ${ }^{16}$ In doing so, it became necessary to determine whether, "the practice which was frequently adopted by the masters for some years after 1936 should be restored and, if so, whether it should be enlarged, restricted or otherwise modified". ${ }^{17}$

The Committee was charged to ensure that any judicial interference with the exercise of the right of possession was to be placed upon a statutory and contemporary footing. In the face of vehement resistance by the Building Societies' Association, the Committee recommended reform. This change was geared to minimise any undue hardship experienced by a mortgagor in transient financial difficulties. ${ }^{18}$ Accordingly, the Committee devised a discretion that would, in appropriate cases, allow the courts to adjourn a summons for possession for a reasonable period so as to allow the borrower to remedy the default. Although the Committee envisaged that a period of six months would normally be sufficient to protect the mortgagor, it declined to impose a limit to the period of suspension or postponement.

The absence of Parliamentary guidance as to the exercise of discretion was to prove particularly problematic in relation to the period of postponement allowed. Despite the Payne Committee's view that a six-month period would usually suffice, the courts were to take a different tack. Although it was quickly established that the court had no jurisdiction to postpone possession proceedings for an indefinite period, ${ }^{19}$ the judiciary did not share the Committee's sense of restraint. The reasonableness of the selected time frame was to depend upon the circumstances of each individual case and relief tailored accordingly. Accordingly, the exercise of discretion necessarily hinges upon the evidence that the court accepts and the weight to be given to it. It is, therefore, ironic that the court traditionally did not insist upon formal evidence of the borrower's ability to discharge the arrears and, moreover, was not obliged to offer reasons for its decision. ${ }^{20}$ This judicial tendency was dismissed by Haley as, "broad brush and conveniently impressionistic". ${ }^{21} \mathrm{~A}$ brace of cases serve well to support his observation.

16 Report of the Committee on the Enforcement of Judgment Debts (1969) Cmnd 3909 at para. 1345

17 ibid., at para. 1378

18 As the Payne Report concluded, "Any man's income or earnings can fall suddenly through no fault of his own, and he should be able to look to the court for any protection he may need against onerous claims arising out of the change of his means and circumstances" (ibid., at para.1386(b)).

19 Royal Trust Co of Canada v Markham [1975] 1 WLR 1416 at 1423; but see the obiter of Buckley LJ in Western Bank v Schindler [1976] 2 All ER 393 at 400 to the effect that, where a mortgagor is not in default under the mortgage, it may be appropriate to postpone possession for an indefinite period.

20 See Cheltenham \& Gloucester Building Society v Turnbull (January 30, 1996 (CA) unreported).

21 M. Haley op.cit., p.492. 
First, in Cheltenham \& Gloucester Building Society $v$ Grant $^{22}$ an order for possession was suspended to be reviewed in twelve months on mortgage payments being made by the Department of Social Security. This was so even though the benefit payments left a monthly shortfall of $£ 135$ and ensured that arrears would continue to accrue. The borrower had sought to convince the court of his prospects for employment, but it was argued on appeal that the evidence placed before the judge had been flimsy in the extreme. The Court of Appeal made clear, however, that it would only interfere with the exercise of discretion in circumstances where it was unquestionably wrong. Although Nourse LJ expressed grave doubts as to whether the same decision would have been reached by the appellate court, he declined to stigmatise it as being plainly wrong. ${ }^{23}$

Secondly, in Bristol \& West Plc $v$ Dace $^{24}$ the borrower built up arrears of $£ 37,000$, having made no repayments for almost three years. A total of four adjournments were granted before a possession order was eventually issued. Thereafter, a total of ten adjournments were granted, including four orders for suspension, each one of which had been specifically breached. Analysing the history of the case, Simon Brown LJ felt that relief had been afforded to the borrower even though the preconditions to the exercise of the section 36 discretion could not possibly have been satisfied. There was simply no evidence that the borrower could meet his monthly instalments, never mind making any repayment of the arrears. Although welfare benefits covered almost half of the current instalments, the borrower was not in a financial position to meet the shortfall. This incautious use of discretion by the lower court had the consequence of protracting litigation and increasing the borrower's overall indebtedness. In such circumstances, the provision of relief to the borrower was neither justified nor meritorious.

\section{The Norgan Guidance}

In the light of such aberrational decision making, specific guidance from the higher courts was required to rein in what Thompson calls "the wide degree of latitude" 25 given to the trial judge. Such guidance emerged from the Court of Appeal in Cheltenham \& Gloucester Building Society v Norgan. ${ }^{26}$ There the appellate court sought to dispel complacency concerning the exercise of discretion and to introduce principle, formality and thoroughness into the decision-making process. The appellate court also attacked the tendency of the county court to standardise the period of postponement as falling somewhere between two and four years. Instead, the starting point from which to determine a reasonable period was presumed to be the remaining period of the mortgage term.

A decade hence, the utility of the Norgan guidance is necessarily to be appraised in light of intervening judicial practices. It is, therefore,

22 (1994) 26 HLR 703.

23 Nourse L.J. explained, "It may well be that another judge would have taken the opposite view. But the discretion in this case was entrusted to this judge" (ibid., at 708).

24 October 2, 1998 (CA) unreported.

25 M. P. Thompson [1995] Conv. 51, p.53.

26 [1996] 1 All ER 449. 
unfortunate that the higher courts have been afforded scant opportunity to develop and refine the section 36 jurisdiction. Nevertheless, the liberal approach as to what constitutes a reasonable period for the repayment of arrears has undoubtedly strengthened the statutory safeguard for those borrowers hoping to retain possession of the family home. Although the decision in Norgan represents what the Grays describe as, "a new willingness to reconstruct the repayment terms of a mortgage", ${ }^{27}$ the policy parameters of the discretion are readily discernible. The mortgagor is to be afforded, "as much protection against eviction as possible, but only if, and for as long as, the mortgagee's investment is safeguarded". ${ }^{28}$ The acid test, of course, is whether consistency and fairness has become a more commonplace feature of possession cases.

In a dense summary, Evans LJ in the Norgan case took pains to isolate the key matters to be addressed by the court in the exercise of its section 36 discretion. ${ }^{29}$ In this respect, the guidance provided is susceptible to the criticism that it fails to prioritise the relevant considerations and gives the impression of being no more than a random list of relevant associated issues. Evans LJ identified the following factors which are to be taken on board in the decision making process. The court must consider how much the borrower can reasonably afford to repay, both now and in the future. If the borrower has a temporary difficulty in meeting his obligations, the court must investigate how long that difficulty is likely to last and take account of the reasons why the arrears have accumulated. The court must also examine the relevant contractual terms and identify what type of mortgage is in issue. In particular, it must deduce when the principal due is to be repaid. Put simply, a decision must be reached as to whether the case is one when the court should exercise its power to disregard accelerated payment provisions under section 8 of the Administration of Justice Act 1973. The court must also decide whether it is reasonable to expect the lender, in the present circumstances, to recoup the arrears of interest either over the whole of the mortgage term or within a shorter (or, indeed, longer) period. The court must, moreover, consider whether it is reasonable for the lender to capitalise the interest or not. In addition, regard must be had to any reasons affecting the security that should influence the length of the period for payment.

The danger attendant to such a general checklist is that a mere consideration of one or more of the listed factors can be relied upon by the court to justify a desired outcome..$^{30}$ Indeed, the marked reluctance of the appellate courts to interfere with the exercise of discretion in the lower courts, save in cases where the exercise is plainly wrong, caters for a diversity of approach on similar sets of facts. Accordingly, it is open to district judges to continue to suspend possession only for limited periods. Others, however, may be prepared to adopt a more flexible approach. For example, the use of stepped

27 K. Gray \& S. Gray, Elements of Land Law, (2005), p.1695.

28 M. Haley op.cit., p.494.

29 [1996] 1 All ER 449 at 463.

30 As Auld LJ explained in Bristol \& West Building Society v Ellis (1996) 73 P. \& C.R. 158 at 162, "It all depends on the individual circumstances of each case, though the important factors in most are likely to be the extent to which the mortgage debt and arrears are secured by the value of the property and the effect of time on that security". 
orders, whereby the level of monthly payments is gradually increased, can be of considerable help to borrowers, but it is by no means a universal practice. Hence, and despite Evans LJ's catalogue of relevant considerations, the degree of mercy shown to a borrower in default may vary greatly between county courts. Where there is sympathy for the borrower, the court can exercise its discretion to adjourn proceedings to manufacture an initial 'wait and see' period within which there may emerge a realistic prospect of the mortgagor paying the sums due within a reasonable period. This was felt to be a proportionate response in the case of a student working to obtain qualifications, which in turn would create an employment opportunity and an ability to pay off mortgage arrears. ${ }^{31}$ Where, however, the arrears cannot be discharged by periodic payments and sale is inevitable, the court is unlikely to favour the borrower. In such a situation, the Norgan approach clearly has no resonance. Instead, the court will usually decline to defer realisation of the security, ${ }^{32}$ sometimes give the borrower a short period of grace $^{33}$ or, rarely, delay possession for a prolonged period, possibly for over one year. ${ }^{34}$ It is a major irony that the discredited practices operating in the pre-Norgan world offered more uniformity than is currently discernible.

The liberality promoted in the Norgan case opens the way, at least in principle, for maximum leniency within the confining parameters of section 36. Not surprisingly, the decision has been generally welcomed as favourable to the borrower in temporary financial difficulties. ${ }^{35}$ Nevertheless, some commentators have sounded a surprising note of negativity. Smith, for example, continues to highlight the danger that lenders will tend towards earlier possession actions, in the knowledge that subsequent default will trigger immediate possession. ${ }^{36}$ This is not, however, wholly convincing as it is equally possible that the mortgagee could delay proceedings so as to allow the indebtedness to grow beyond that which can be discharged by periodic payments. Sparkes is also critical and accuses the Court of Appeal of, "deliberately flouting existing county court practice ... making one feel sorry for the lender" ${ }^{37}$ This reasoning, perhaps, underplays the point that Norgan applies only when there is sufficient equity in the property and disregards the financial reality that the mortgagee will charge interest on the arrears and enforcement costs to generate even more profits from the transaction. It is, moreover, to be appreciated that the lender in the majority of repossession cases will seldom be as well protected as on the facts of Norgan. There the mortgage term had thirteen years remaining, the outstanding arrears amounted only to $£ 7,000$ on a loan of $£ 90,000$ and the equity in the property was estimated at around $£ 225,000$. Put simply, there can be a no more

31 Skandia Financial Services Ltd. v Greenfield [1997] CLY 4248.

32 In Mortgage Service Funding plc v Steele April 10, 1996 (CA) unreported, Nourse LJ had little sympathy for the borrower, "Unless there is firm evidence that a particular sale is about to be completed, it is not the practice of the court to prevent the mortgagee from enforcing his remedy of obtaining possession and exercising his own power of sale over the property".

33 In Cheltenham \& Gloucester Plc v Krausz [1997] 1 WLR 1558, e.g. the borrower was allowed a period of 28 days.

34 See National \& Provincial Building Society v Lloyd [1996] 1 All ER 630.

35 See, e.g. M. Haley, op. cit., p.496.

36 R. Smith, Property Law, (2003), p.585.

37 P. Sparkes, A New Land Law, (2003), p.671. 
convincing case for the adoption of the lifetime of the mortgage as the reasonable period in which to discharge the arrears. This, at least in part, may explain the infrequency with which the domestic courts have been called upon to revisit Norgan.

\section{The Northern Ireland Approach}

It is interesting that the Norgan decision has also been subject to criticism by the Northern Ireland courts. There, and in marked contrast to England and Wales, the limits of this aspect of borrower protection have been tested regularly and variously in the last ten years. In particular, the courts have grappled with the power to stay in the case of a compromise consent order, ${ }^{38}$ the jurisdiction of the Master (Enforcement of Judgments) to stay or adjourn enforcement in mortgage possession cases $^{39}$ and the concept of a reasonable period to allow the borrower to negotiate a private sale of the property. ${ }^{40} \mathrm{It}$ was National \& Provincial Building Society v Lynd,${ }^{41}$ however, that marked a significant and protracted departure from the practice of the courts in England and Wales. ${ }^{42}$ In an overt criticism of Norgan, Girvan J explained, "The inference of a presumption in favour of the length of the term of the mortgage being prima facie the relevant period is not in my respectful view a logical or justifiable inference to be drawn from the inherent context of the legislation". ${ }^{43}$ He pointed out that, until the decision in Norgan, the Northern Ireland approach had been to follow the restrictive practices of the English courts. For example, in National \& Provincial Building Society $v$ Williamson and Humphrey ${ }^{44}$ a reasonable period was regarded as a 'relevantly limited' period with an outer limit of between four and five years. In the Lynd case, Girvan $\mathbf{J}$ appreciated the checklist drawn up by Evans LJ and accepted that the lifetime of the mortgage may well be a reasonable period in the circumstances of a given case. ${ }^{45}$ Nevertheless, he argued that the Court of Appeal had overstepped the mark in promoting a general presumption in favour of the full term of the mortgage.

This approach is clearly more exacting than that applying to borrowers in England and Wales. It is not simply that the Norgan presumption of a reasonable period is viewed as being an erroneous starting point. The courts in Northern Ireland also require of the defaulting borrower, his "best realistic proposals" for paying off arrears. ${ }^{46}$ The court then assesses the appropriateness of the suggested figures against the particular circumstances

38 Northern Bank Ltd v Jeffers [1997] NI 497.

39 Halifax plc v Seawright [2000] NIJB 71; see D. Capper, "The Enforcement of Judgments for Possession of Land" (2002) 53 NILQ 90.

40 Northern Bank Ltd $\mathrm{v}$ Mallett [2001] NICh 7.

41 [1996] NI 47. On the facts, the Lynds had been offered a series of opportunities to repay mounting arrears totalling almost $£ 9,400$ on an outstanding loan of $£ 24,800$ repayable over 17 years

42 See H. Wallace (1986) 37 NILQ 336 for a general discussion of mortgagees and possession as they relate to Northern Ireland.

43 [1996] NI 47 at 58.

44 [1995] NI 366.

45 On this point Girvan J was able to "respectfully agree" with Evans LJ, holding that his statement of relevant considerations, "correctly in view, impresses on the court the need to look at all the circumstances of the case" (above at 56).

46 National \& Provincial Building Society v Lynd [1996] NI 47 at 60. 
of the individual case. Given the clear breach of the contractual agreement between the parties, the Northern Ireland approach seeks to avoid a case where the borrower pays less over a longer timeframe merely because it suits him to do so. ${ }^{47}$ This seemingly overlooks both the policy and practicality of Norgan, which, when applied, allows the court to stem multiple applications under section 36 and, thereby, save court time. In Norgan, Waite LJ remarked of the case before him that the parties had been before the court with depressing frequency with the costs incurred in relation to those attendances being borne by the borrower. In adopting at the outset the period of time most favourable to the borrower, he emphasised that section 36, "should not be employed repeatedly to compel a lending institution which has already suffered interruption of the regular flow of interest to which it was entitled under the express terms of the mortgage, to accept assurances of future payment from a borrower in whom it has lost confidence". ${ }^{48}$ This entails that the borrower has a single opportunity to get back on track with mortgage repayments and that, on any subsequent default, the sympathy of the court will evaporate. Hence, its effect is to limit the escalation of indebtedness arising from multiple applications under section 36 and the corresponding charges and interest levied by lenders in such circumstances.

Such an approach would have benefited all parties in Halifax Plc $v$ Seawright, ${ }^{49}$ where a succession of extended opportunities were offered to the borrowers to meet their repayment obligations despite repeated failures by them to honour their past repayment promises. Not surprisingly, on appeal, Girvin $\mathbf{J}$ expressed dissatisfaction with the progress of the enforcement proceedings and the manner in which the case had been handled, lamenting the lengthy delays and the overt failure to enforce the High Court's order for possession. As regards section 36, Girvan J drew from Northern Irish case law the principle that, where the court is exercising its section 36 discretion, it must be satisfied that there is a likelihood of the arrears being paid off within a fairly limited period. ${ }^{50}$ Without mention of Norgan or allusion to the lifetime of the mortgage, he concluded that the period of fifteen years, which it would have taken for the arrears to be cleared, could not be construed as reasonable. It has been suggested that the decision in Lynd represents a "pragmatic and balanced approach". ${ }^{51}$ The inference to be drawn from such suggestions is that Norgan is too borrowerfriendly and based upon the unsteady foundation that most borrowers are honourable in their intentions to meet their mortgage repayments. It is contended that, without the Norgan presumption, the court would be more able to consider what is fair and just for both parties. Such arguments are, however, questionable. Given the social importance attached to the preservation of the family home, and the compelling argument that the mortgagee receives "substantially what he bargained for, albeit at a later

47 Girvan $\mathbf{J}$ noted ibid., that this may be attractive to the borrower even though interest continues to be payable on arrears.

48 [1996] 1 All ER 449 at 460.

49 [2000] NIJB 71.

50 Namely National and Provincial Building Society v Williamson [1995] NI 366 and National and Provincial Building Society v Lynd [1996] NI 47.

51 H Conway and S Grattan, "Northern Ireland: Falling Behind or Forging Ahead?" in E Cooke (ed.) Modern Studies in Property Law (vol. 2, 2003), p.214. 
date", ${ }^{52}$ surely it is not inappropriate to cater, where possible, for the repayment of arrears over the lifetime of the mortgage. Furthermore, the lesson from post-Norgan case law is that the presumption is readily displaced when there is a real threat to the lender's security. The case of Realkredit Danmark $v$ Brookfield House ${ }^{53}$ for example, clearly demonstrates that where the debt has spiralled out of control, there is nothing that the court can or will do for the borrower. In the context of a property valued at $£ 1.5$ million and an amount due under the mortgage of $£ 2,175,000$, the borrower was unable to provide evidence of an income sufficient to meet the mortgage repayments. The Court of Appeal emphasised that, in such circumstances, it would be unreasonable to take the remainder of the mortgage as an appropriate period in which arrears should be repaid.

\section{Practice and Policy}

It is noteworthy that in both Norgan and Lynd the courts were well aware of the industry standards to which lenders subscribed and, notwithstanding the divergence of judicial approach, prepared to gauge the conduct of the mortgagee against these adopted statements of good practice. The judgment in Norgan is clearly underpinned by the explicit policy directive from the Council of Mortgage Lenders that mortgagees should seek possession only as a last resort. This direction influenced Waite and Evans LJJ as to their perception of the logic and spirit of the legislation so as to justify the interference with the sanctity of the contractual agreement and to achieve a realignment of the parties' competing claims. Indeed, Evans LJ was, in particular, confident to assert that, "given these statements of policy ... it cannot be wrong or unreasonable to consider what the prospects are of the borrower paying the arrears of interest in full by the end of the term". ${ }^{54}$ The pursuit of possession only as a last gasp measure offered the appellate court a licence to exploit favourable factual circumstances for the benefit of Mrs Norgan. Nevertheless, in Lynd Girvan J believed that this approach did not have sufficient regard of the effectiveness of self-regulation. He claimed that institutional lenders, "do not lightly resort to the court and usually only do so after they have attempted to follow through the guidelines set out in the CML statement". ${ }^{55}$ Accordingly, by the time the case reaches court, "there is a serious history of default and broken promises". ${ }^{56}$ In Lynd, it was the assumption that all lenders follow these best practice guidelines which led to the conclusion that a reasonable period should only be a relatively short period.

Despite the clear divergence in orientation and outcome, both decisions demonstrate that the stated policies of institutional lenders are to be employed to inform the exercise of judicial discretion. Unsurprisingly, therefore, the best practice prescription for mortgage lenders has assumed a much greater currency during the last decade for judges, commentators and regulators alike. One noteworthy illustration of the judicial focus upon the published practices of lenders can be found in Governor \& Co of the Bank of

52 J. Morgan "Mortgage Arrears and the Family Home" (1996) 112 LQR 553, p.556.

53 January 21, 1999 (CA) unreported.

54 [1996] 1 All ER 449 at 462.

55 [1996] NI 47 at 62.

56 ibid. 
Scotland $v$ Ladjadj and Haya Tal. ${ }^{57}$ In this case, the Court of Appeal launched a scathing attack upon the inconsistent, unclear and unfair manner in which some lenders craft their contractual dealings with the consumer. In an effort to calculate the true extent of the borrowers' contractual indebtedness, Laws LJ bemoaned that, "the respondents' documentation is disgracefully sloppy and well capable of creating confusion". In his eyes, the contract before him constituted an, "arithmetical maze", causing disagreement between lender and borrowers as to the arrears deficit. Remarkably, the divide between the respective calculations was in the region of $£ 40,000.58$ Laws LJ regarded it as, "nothing short of scandalous that a major lending institution should foist this jigsaw puzzle of a contract on the borrowing public". Robert Walker LJ agreed and felt it "deplorable that the defendants' right to their home should depend on the interpretation and combined effect of no fewer than four contractual documents, which do not use, as they should, a clear and consistent terminology". Although this is no more than a specific case law example, the scope for an inconsistency of the treatment of borrowers is readily apparent. On a more general level, the absence of uniformity in the published policies of lenders has also been exposed as a formidable obstacle to consistency and fairness in the enforcement process. As Whitehouse observes:

"Some lenders will seek a court order immediately upon default. Others will wait for up to 18 months after default before initiating court action. This leads to inconsistency in the treatment of mortgagors in default, with some borrowers being allowed the opportunity to clear their arrears without court action and additional court costs, and others being subject to court proceedings immediately upon default". 59

In light of the varied exercise of judicial discretion and the disparate and often unhelpful policies of lenders, it is instructive to consider the impact of the recent statutory regulation of mortgages. From October 31, 2004, the acquisition mortgage market has fallen under the regulatory supervision of the Financial Services Authority. The imposition of a new framework has been long awaited. In July 1999, the Government issued 'Regulating Mortgages', a preliminary consultation document, which sought comments on the extent to which mortgages should be regulated. The Government proceeded in January 2000 to announce its intention to pursue a policy of statutory regulation of mortgage lending. Two consultation papers were produced. ${ }^{60}$ In December 2001, the Government set in train plans to extend the scope of regulation to include mortgage arranging and advice, entailing that those aspects of the draft rules required re-evaluation. Following further

57 January 28, 2000 (CA) unreported.

58 It is of note that mediation was put forward as a recommended means by which the parties should sort out their differences. Laws LJ described the alleged refusal of the lender to take part as being, if substantiated, "wholly lamentable".

59 L. Whitehouse, "The Right to Possession: The Need for Substantive Reform" in P. Jackson, D. C. Wilde, The Reform of Property Law (1997), p.161.

60 Mortgage Regulation: The FSA's high level approach (CP70) was published in November 2000 and preceded CP98 The Draft Mortgage Sourcebook, including policy statement on CP70, published in June 2001. 
consultation $^{61}$ and additional policy statements, ${ }^{62}$ the Financial Services Authority published its final conduct of business rules. ${ }^{63}$ Its modern manifestation adopts the guise of the 'Mortgages: Conduct of Business Sourcebook' (MCOB). ${ }^{64}$ In the light that some of the duties imposed on 'responsible lenders' are relevant to the process of enforcing residential mortgages, an improvement to the adequacy of protection for borrowers was a reasonable prospect. Two aspects of these mortgage specific rules are of relevance: first, the provision of arrears information and, secondly, the policy and procedure for dealing with arrears.

\section{Provision of Arrears Information}

The Glossary to the Financial Services Handbook ascribes a particular meaning to the concept of 'arrears'. ${ }^{65}$ Where the mortgage involves a regular payment plan, a consumer is considered to be in arrears when two regular payments have been missed. As regards a mortgage that does not involve a payment plan (for example, a secured overdraft), a consumer will be in arrears where, say, the agreed overdraft limit has been exceeded for longer than one month or the borrower remains in breach for more than one month. When a customer is in arrears, new requirements are imposed in relation to the provision of prescribed information by the lender. ${ }^{66}$ The obligation is to act as soon as possible or, in any event, within fifteen working days of becoming aware that the customer is in arrears. ${ }^{67}$ By way of initial response, the customer should be provided with the current FSA information sheet on mortgage arrears and a list of the payments that have been missed or merely paid in part. Information should cover the total sum of the payment shortfall, any charges incurred as a result and "an indication of the nature (and where possible the level) of the charges" that the customer is likely to incur as a result of remaining in arrears. If the customer's account had previously fallen into arrears within the preceding 12 months, but the earlier arrears had been discharged, the lender must either issue a new initial response or provide a written statement of the payments due, the actual payment shortfall, any charges incurred and the total outstanding debt. ${ }^{68}$ The customer should in the

61 CP 146 The FSA's Approach to Regulation Mortgage Sales (August 2001); CP186 Mortgage Regulation: Draft Conduct of Business Rules and Feedback on CP 146 (May 2003).

62 Feedback on CP 98 (The Draft Mortgage Sourcebook) (August 2002); Regulating Mortgage Sales: Final Conduct of Business Rules - Feedback on CP186 and Made Text, vol. 1, (October 2003).

63 Regulating Mortgage Sales: Final Conduct of Business Rules - Feedback on CP186 and Made Text, vol. 2, (October 2003).

64 This has been incorporated into the Financial Services Handbook: see Mortgages: Conduct of Business Sourcebook Instrument 2003, http://www.fsa.gov.uk/ handbook/legal_instruments 2003/200371.pdf. The Sourcebook is soon to be subject to further amendment: see Mortgages: Conduct of Business Sourcebook (Home Reversion and Home Purchase Activities) Instrument 2006.

65 See also Feedback on CP 98 (The Draft Mortgage Sourcebook) op. cit., para.4.28.

66 MCOB 13.4.1R.

67 The original timeframe of five working days was increased following the consultation process.

68 MCOB 13.5.1R. 
latter case (but not, seemingly, the former) be warned at this stage that repossession is amongst the possible consequences of remaining in arrears.

Where the arrears are attracting charges, the lender must send the customer a regular written statement of payments due, the actual payment shortfall, the charges actually incurred and the total debt. ${ }^{69}$ The requirement to furnish a written statement will still apply even when a repayment plan has been agreed between the parties and the borrower is abiding by it. ${ }^{70}$ Before commencing an action for repossession a lender must provide a written update of arrears information and a clear statement of the action the lender intends to take regarding repossession. ${ }^{71}$

The early detection and treatment of arrears should produce clarity and reliability, in addition to the speedier resolution of minor cases of default. More specifically, the new regulatory requirements should go some way to eradicate the, at times, woeful inadequacies of lenders' policies and practices as highlighted by the courts in recent times. ${ }^{72}$ At the very least, the borrower should be provided with accurate details as to on-going liability and the enforcement steps to be taken by the lender. Nevertheless, a mere knowledge of the consequences of liability hardly empowers a borrower who is facing the potential loss of the family home.

\section{Policy and Procedure for Dealing with Arrears}

It is a fundamental requirement that lenders have in place written policies and procedures for dealing fairly with customers in arrears. ${ }^{73}$ Not surprisingly, lenders are expected to operate in accordance with these published guidelines. ${ }^{74}$ The policy and procedures must oblige the lender to use reasonable efforts to reach an agreement with a customer over the method of repaying any payment shortfall, having regard to the desirability to agreeing with the customer an alternative to taking possession of the property. ${ }^{75}$ Where relevant, the lender must liaise with the borrower's financial adviser regarding the payment shortfall. ${ }^{76}$ The lender should, moreover, adopt a reasonable approach to the time span over which arrears should be repaid, having particular regard to the need to establish a repayment plan that is practical in terms of the circumstances of the customer. In the 'Draft Mortgage Sourcebook', specific reference was made

69 ibid. Although provision was made for a monthly statement in the Draft Mortgage Sourcebook, op. cit., this requirement has been relaxed to a minimum of "at least once a quarter".

70 MCOB 13.5.2G(3).

71 MCOB 13.4.5R. A lender must also ensure that a customer is informed of the need to register for housing with the local authority.

72 See, for example, Governor \& Co of the Bank of Scotland v Ladjadj and Haya Tal above.

73 See generally MCOB.13.3.2E(1).

74 MCOB. 13.3.1.R(2).

75 This entails that customers should be given a reasonable period of time to consider any proposal for payment: MCOB 13.3.4(1).

76 The formulation of this sub-paragraph has been altered from that proposed in the Draft Mortgage Sourcebook, which obliged the customer merely to 'request' rather than arrange, and specified, moreover, that the third party source of advice should be free to the customer: CP98, June 2001, Annex B, MORT 12.3.2E(1)(b). 
to Cheltenham \& Gloucester Building Society v Norgan. It was clearly anticipated by the Financial Services Authority that the Norgan approach would be followed in the determination of what might be a reasonable repayment period. ${ }^{77}$ This ethos also pervades the MCOB where it is made explicit that, "In appropriate cases this will mean that repayments are arranged over the remaining term of the regulated mortgage contract" ${ }^{78}$ Unless it has good reason not to do so, a lender should additionally grant a customer's request to a change to the date on which, or the method by which, payment is due. If it refuses this request, the lender must give the customer a written explanation of its reasons. ${ }^{79}$ Finally, the repossession of the property should occur only where all other reasonable attempts to resolve the problem of arrears have failed. ${ }^{80}$

The regulatory reforms concerning the policy and procedure for dealing with arrears are disappointing and limited. The overriding concern is that a lender should give proper consideration to arrears issues, follow a documented approach and ensure that proper internal systems are put in place for the fair treatment of customers. ${ }^{81}$ Such goals are purely matters of form and operational procedure. As to the substantive rules governing borrower protection, there is nothing that is innovative (at least in England and Wales) in the expectation that firms should have regard to the practicality of any repayment plan or that, in appropriate cases, repayments might be rescheduled over the remaining term of the loan. This regulatory response adds nothing to that adopted by the judiciary over the last ten years and does not operate to increase further the protection of borrowers in temporary financial straits. It is ironic that, instead, it might cause judicial sympathies to sway in favour of the institutional lender. First, it is possible that judges will be better disposed towards lenders who evidence the alteration of the terms of the mortgage contract in the prescribed ways. Secondly, it is likely that far fewer cases will come before the courts when the postponement of possession is a probable outcome. Thirdly, it is likely that more borrowers will have already benefited from a Norgan style repayment plan before the case ever reaches court. Of course, where there is little evidence of a desire on the lender's part to adhere to the spirit of the regulation, judicial sympathies will understandably shift towards the borrower. Nevertheless, it is only when the circumstances fall within the parameters of the Norgan liberality that the court will be able to maintain a roof over the borrower's head. As those parameters are likely to have already been reached, it is difficult to see how such sympathy can translate into effective relief.

There is no question that MCOB will lead to increased transparency. More questionable is whether the rules will produce an equivalence of treatment for different borrowers in regulated contracts with different lenders following different enforcement policies. It is to be regretted that there remains scope for the adoption of highly divergent approaches and the standard expected cannot, in any sense, be regarded as exacting. A range of voluntary industry

77 See C.P. 98 at para.15.7.

78 MCOB 13.3.6G.

79 MCOB 13.3.2E

80 ibid.

81 MCOB 13.3.3G. 
standards have long been published ${ }^{82}$ and the Conduct of Business rules draw heavily upon such past precedents. ${ }^{83}$ While statutory, as opposed to voluntary regulation, would mark an advance in consumer protection, there is broad industry opposition to this proposal. It is thought that Parliament should not dictate the credit management policies that individual lenders are to adopt. The Consultation Paper, which sets out to explain the policy underlying the rules, makes it abundantly clear that the aim is merely to set minimum standards surrounding the treatment of customers and not to intervene substantially in management issues. ${ }^{84}$ Hence, there is no intention to dictate the enforcement policies of lenders. A telling example is to be found in the MCOB suggestions as to alternatives to repossession that might be considered. These options remain the same as those already embraced by the Council of Mortgage Lenders, that is, to extend the term or change the type of regulated mortgage contract; to defer payment of interest due or to treat the payment shortfall as if it was part of the original amount borrowed. The wording, moreover, is wholly bereft of obligation. The guidance reads that, "depending on the individual circumstances, a firm may wish to do one or more of the following ...".85 The need persists for a standardised enforcement policy, procedure and process that apply to all mortgage lenders. While increased regulation concerning the provision of information and the promotion of transparency is to be welcomed, these changes alone are woefully insufficient to safeguard effectively the interests of the borrower in default.

\section{Conclusion}

Over the preceding decade, the UK mortgage market has become increasingly diverse and competitive. This is evident from the range of products offered and the type of consumer to which those products are aimed. These years have also witnessed staggering increases in bankruptcy and personal indebtedness, together with the continued and unparalleled demand for secured and unsecured borrowing. The proliferation of mortgage products, in combination with a growth in the volume of "non-conforming" mortgages (such as buy to let, lifetime and adverse credit mortgages), serves to accentuate the need to reconsider what is the most appropriate framework for borrower protection. This is plainly demonstrated by the practice of adverse credit lending (i.e. lending to borrowers who have previously experienced credit difficulties $\left.{ }^{86}\right)$, which is estimated by the Council of

82 E.g. the Council of Mortgage Lenders adopted a statement of practice on the handling of arrears and repossessions and employed a voluntary agreement on the recovery of mortgage shortfall: see http://www.cml.org.uk.

83 The repossession of property 'only where all other reasonable attempts to resolve the position have failed' (MCOB 13.3.2E(1)(f)) is a simple reformulation of the Council of Mortgage Lender's established policy to take possession only as a last resort.

${ }^{84} \mathrm{CP} 98$, para.15.2. The rules are drafted, "in such a way that firms are able to adopt alternative approaches" (Feedback on CP 98 (The Draft Mortgage Sourcebook) op. cit., para.4.31).

85 MCOB 13.3.4G(1).

86 This can include, e.g. borrowers with a history of County Court Judgments, bankruptcy or individual voluntary agreements, default, and poor credit or loan arrears. 
Mortgage Lenders to now account for around at least 5-6\% of gross industry advances. ${ }^{87}$ The advent of such mortgages has introduced and helped sustain home ownership for those borrowers who could not otherwise afford but, significantly, it exposes the consumer to an increased likelihood of future repayment problems. Indeed, as the Council of Mortgage Lenders acknowledge, "Adverse credit lending carries a higher risk profile than prime lending, and this is reflected in a worse default performance. The rapid growth in consumer demand for such lending over recent years has contributed to the overall deterioration in arrears and possessions at the industry level" ${ }^{88}$ It is estimated, moreover, that around two-thirds of borrowers who obtain an adverse credit mortgage do so not as a means to access home ownership, but to consolidate debts or to recover from previous debt difficulties. ${ }^{89}$

The procedural regulation of mainstream institutional lenders marks a noteworthy development of the post-Norgan era. The new regime introduces standards applying to a broad spectrum of activities linked to advice and lending, and aims to treat fairly customers with mortgage payment problems, It is apparent that this regulation will undoubtedly temper the approach of lenders to aspects of enforcement, such as their treatment of customers in arrears and the taking of possession. This code of behaviour will see a new threshold against which the conduct of lenders will be measured in possession actions, perhaps most notably in the Northern Ireland context.

It cannot be denied, however, that the interests of the Financial Services Authority lie in the governance of service standards rather than the structural development of mortgage law. To this extent, MCOB was never intended to cover either the fairness of the mortgage relationship or the assertion and exercise of rights and remedies. Hence, the omission by Parliament to implement long-standing Law Commission recommendations, as to the strengthening of the substantive law, is to be regretted. It is regrettable also that there is no single regulatory context in which all mortgage lending is considered. The Consumer Credit Act 1974 (as amended) continues to regulate borrower protection in the second mortgage market. ${ }^{90}$ In stark contrast to the protections afforded to mortgagors under the general law, and the apathy in respect of substantive law reform, borrowers caught within this different regulatory framework will now benefit from enhanced protection in the grant of time orders as a result of a Government initiative. The Government has, moreover, long planned to encourage the increased use of time orders as part of its wider strategy of tackling over-indebtedness. ${ }^{91}$ The strategic priority of the Government is to achieve, "a reduction in the number of debt cases brought to court, with improved engagement between parties leading to the earlier resolution of debt problems" 92 and, as regards matters

87 CML Housing Finance, Issue 10, 2006, p.4.

88 ibid., p.1.

89 ibid., p.6.

90 The abolition of the $£ 25,000$ financial ceiling (section 2) will see more loans fall under CCA regulation.

91 The Task Force on over indebtedness was established in October 2000 to address issues relating to the level of consumer debt in British Society.

92 DTI, "Tackling Overindebtedness", Annual Report, 2006, London, p.11. 
that can only be resolved through the courts, "improvements in the efficiency and speed with which cases are handled". ${ }^{93}$

The availability of the time order extends to a mortgagor an opportunity to apply to the court for a rescheduling of payments due under a Consumer Credit Act regulated agreement. A time order may be granted where possession is sought by the lender or, alternatively, on the express application of a borrower. Although a parallel between the time order and the discretion afforded under Administration of Justice Acts is easy to draw, there exist key differences. In particular, the court may make a time order where it considers it just to do so and, unlike section 36, it is not concerned with whether the borrower is likely to repay within a reasonable period. ${ }^{94}$ Unlike under section 36 , the court is also permitted to amend the terms of the agreement where it is just to do so by extending the term of the agreement or altering the rate of interest to be paid. ${ }^{95}$ Section 129 of the 1974 Act (as amended) extends to the debtor the opportunity to apply for a time order on receipt of a notice of sums in arrears. ${ }^{96}$ Under section 129A, a debtor must give notice in writing to signal the intention to make the application for a time order. The debtor must also outline the details of any proposal as regards the making of payments under the agreement. If no agreement can be reached between the parties within 14 days of the service of the notice, the debtor may then make an application to the court. ${ }^{97}$

The availability of time orders demonstrates that, when the political will is present, Parliament can put in place effective, flexible and practical safeguards to protect borrowers who are in default. Unfortunately, as regards the reform of mainstream mortgage law that will is presently non-existent. In the absence of such reforms, the Norgan approach will continue to represent the last hope of the mortgagor in temporary financial straits.

93 ibid.

94 The possibility of overlap between these provisions has always been apt to cause uncertainty: see First National Bank v Syed [1991] 2 All ER 250, where an order of the lower court was mistakenly made under the auspices of the Administration of Justice Acts and required reclassification by the Court of Appeal as a time order under the Consumer Credit Act.

95 Consumer Credit Act 1974, s.136; see also Fair, Clear and Competitive: The Consumer Credit Market in the $21^{\text {st }}$ Century, (Cm 6040, 2003, DTI) at para.5.73.

96 As required under the new sections $86 \mathrm{~B}, 86 \mathrm{C}$.

97 This requirement has no application to debtors in receipt of default notices under s.87 of the 1974 Act. 